\title{
PRINCIPLE OF IRREMOVABILITY OF JUDGES: JUDICIAL INDEPENDENCE IN HUNGARY
}

\author{
NGE NGE AUNG \\ Geza Marton Doctoral School of Legal Studies, University of Debrecen, \\ Kassai út 26, 4028, Debrecen, Hungary \\ E-mail address: ngengeaung80@gmail.com \\ ORCID: https://orcid.org/0000-0002-3620-2849
}

\begin{abstract}
Aim. This research paper is to highlight the freedom of the judges who represent one of the three branches of governments, which is still lacking in both the developing and developed countries. Their freedom of speech, freedom of expression and freedom of making decisions can be defined as the independence of the judiciary.

Methods. The research method used in this paper is the case study approach by learning the historical background of Hungary with the connection of the EU's legal standards that can support work to do analysis both theoretically and practically.

Results and Conclusion. The results of the work can be applied in some countries that are not linked to each other with regional integration policy (like Myanmar and ASEAN Countries) and the functions of the Constitutional Courts need to be updated to protect the fundamental or basic rights effectively at a national level and to be free from the influence of the legislature and the executive.

Cognitive value. The value of the paper is to learn the best solutions for reconciliation between the three branches of government, especially to respect the independence of the judiciary and the principle of irremovability of judges widely accepted in not only international standards but also EU norms.

Key words: judicial independence, irremovability of judges, legal norm of European Union, Constitutional Court
\end{abstract}

\section{INTRODUCTION}

Tungary was a socialist state before 1989 and after that it became a democracy. 1 The Constitutional Court was established on 19 October 1989. It was a sign of attempting to promote democracy and human rights through the judiciary. One year later, the death penalty was abolished on 24 October (The Constitutional Court of Hungary, 1990). It shows that Hungary respects human rights because the right to life (Article 3) is the most fundamental right under the UN Charter (United Nations, 1948). Then, Hungary signed the European Convention on Human Rights (hereinafter: ECHR) on 6 November 1990 and in 2004 Hungary 
became a member of EU. In fact, a state in Europe that wants to join with the EU should fulfil the formal requirements such as free market, stable democracy, rule of law and follow the EU legislation (European Commission, 2016).

Thus, Hungary proved that the state respects democracy by setting up the Constitutional Court in 1989, abolishing the death penalty and signing the ECHR in 1990. These are the efforts that Hungary made to change from the socialist system into democracy. It can be said that judicial independence existed with the rule of law consistent with the legal standards of the EU's framework.

\section{EUROPEAN COURT OF JUSTICE (ECJ)}

The European Court of Justice (hereinafter: ECJ) is composed of one judge from each EU country and eleven Advocate Generals. It is also be known as Chief Justice of the European Union (CJEU).

The main duty of the ECJ is to interpret EU law. There are two sources of EU law: primary law that is included the Treaty on European Union (TEU) and the Treaty on Functioning of the European Union (TFEU) and the secondary source of recommendations, opinions, decisions, regulations and directives. Some of the researchers define supplementary law as the third source of EU law (European Commission). If a case before the Constitutional Court is related to the EU values, a Member State shall transfer that case to the ECJ for a preliminary ruling (Consolidated Version of The Treaty on the Functioning of the European Union, 2008). The Union is founded on the values of respect for human dignity, freedom, democracy, equality, the rule of law and respect for human rights (Article 2, Treaty on European Union).

\section{REFORM 2011 IN HUNGARY}

Two different high courts were established under the Constitution 2011 in Hungary, which replaced the Constitution 1949. It entered into force on 1 January 2012. The Constitutional Court is the highest court to protect the Constitution (Hungary's Constitution of 2011, 2019). The former Supreme Court was replaced with the Curia (the historical name) and it is the highest judicial body (Hungary's Constitution of 2011, 2019).

\section{IMPORTANT FUNCTIONS OF THE CONSTITUTIONAL COURT}

Competencies of Constitutional Courts are different in general. The main aims are to promote democracy and to protect the fundamental rights vested under the Constitution. The Constitutional Court of Hungary has the important functions of:

- Ex Ante Review (Preliminary Norm Control)

- Ex Post Review (Posterior Norm Control) 
- Judicial Initiative for Norm Control in Concrete Cases

- Constitutional Complaint (Detre, 2019).

These functions are the powers of the Court to protect the fundamental rights effective theoretically. In Myanmar, the Constitutional Tribunal has not vested these kinds of functions even in theory, therefore, the Court had faced a hard time in practice and then the first nine judges of the Constitutional Tribunal were impeached by the legislature and they resigned themselves.

\section{CONSTITUTIONAL COMPLAINT}

The function of the constitutional complaint is important for the citizen who has been affected by a concrete case or by the application of a legal provision contrary to the Fundamental Law and may submit a constitutional complaint to the Constitutional Court (Hungary's Constitution of 2011, 2019).

The constitutional complaint is a new type of complaint, introduced instead of the actio popularis. In a justified complaint procedure, the Constitutional Court has the competence to annul the challenged legal norms which are not in harmony with the Constitutional law and break the petitioner's fundamental rights. The real or genuine constitutional complaint enables the Court to provide a constitutional remedy against judicial decisions (Detre, 2019). According to some constitutional law researchers from Hungary, "the main function of the Constitutional Court is supplemented by a function serving a more direct protection of fundamental rights in the form of the real constitutional complaint procedure in some European countries like Germany, the Czech Republic, Croatia and Slovenia" (Somody, Vissy, 2011, p. 96). The Fundamental Law abolished the so-called actio popularis and introduced a more complex system of review, in which the emphasis is on the individual concerns, i.e. the system of constitutional complaints (Szalbot, 2019).

\section{CASE STUDIES}

The Commissioner for fundamental rights submitted to the Constitutional Court request for a review of the whole of the Transitional Provisions of the Fundamental Law of Hungary (hereinafter: TPFL) with regard to being contrary to the Fundamental Law and asked for the annulment of it under section 24 (2), Act CLI of Constitutional Court (2011).

There were some effects of the new fundamental law that came into force on 1 January 2012 in Hungary. As the Transitional Provisions to the Fundamental Law 2011 entered into fore on the same day. According to Article 11 of the law, the legal successor of the Supreme Court, the National Council of Justice and its President shall be the Curia for the administraton of Justice and the mandate of the President of the Supreme Court and the President and members of the National Council of Justice shall be terminated when the Fundamental Law come into force (The Transitional Provision to the Fundamental Law of Hungary, 2012). Under Article 26 (2) of the Fundamental Law, with the exception of the Presi- 
dent of the Curia, no judge may serve who is older than the general retirement age (The Transitional Provision to the Fundamental Law of Hungary, 2012). The same rules were applicable to 236 judges, 100 prosecutors and 60 notaries who had to retire in 2012 (Vincze, 2014). This manner of removing judges and legal officers made judicial independence fade away under the discrimination of age and violation of the EU directive. The Venice Commission examined that this issue not from the age discrimination but its effect on judicial independence (the Opinion no 665/2012, 2012 by the Venice Commission).

The Vice President of the Supreme Court submitted a constitutional complaint to the Constitutional Court (2011), claiming that the termination of his position violated the rule of law the prohibition of retroactive legislation and his right to a remedy (45/2012, XII.29).

The Constitutional Court rejected this complaint by justifying the reason for reorganisation of the judicial system and the important changes in the tasks and competencies of the President of the Curia. In fact, the competencies of the President of the Curia had already been promoted. Attila Vincze also concluded in this way that the premature termination of the claimant's term of office weakened the guarantees for the separation of powers, and was contrary to the prohibition of retroactive law-making and breached the principle of rule of law and the right to a remedy" (Hungary: Act CLI of 2011 on the Constitutional Court, 2011, p. 206).

The European Commission alleged that Hungary had forced the retirement of the judges made in a binding EU legislation known as the anti-discrimination directive (Directive 78/2000/EU) violated (Directive 78/2000/EU). The Commission hence filed the case before the ECJ (European Commission v Hungary C-286/12). In fact, Hungary had the obligation to submit the case to the ECJ as a preliminary question due to Article 267 of TFEU (Vincze, 2014).

The EU accepts a country that values democracy and human rights as a member of the EU. After becoming a member of the EU, that country should obey the values of the EU prescribed in the EU treaties. Otherwise, the EU has the power to sanction and fine that country because of the failure to follow the uniformity of EU countries (Council of the European Union, 2018).

\section{IRREMOVABILITY OF JUDGES; EU STANDARD OF JUDICIAL INDEPENDENCE}

The ECJ decided that Hungary violated the EU law, but the removed judges could not get back their former positions. It could be criticised that there were no effective remedies under politic if public servants who had had their fundamental rights violated, even though those rights are values of EU. The principle of irremovability of judges under the European standards on the independence of the judiciary and rule of law notes as follows: "Judges, whether appointed or elected, shall have tenure until a mandatory retirement age or the expiry of the term of office" (Vincze, 2014, p. 206). Regarding this principle of irremovability of judges, Andras Baka, whose right to a hearing was rejected before the national 
Constitutional Court, submitted a suit against Hungary to the European Court of Human Rights (hereinafter; ECtHR) in 2012. He was the former President of the Supreme Court of Hungary and was forced into retirement when the Constitution 2011 came into force in 2012, under which the general retirement age had been changed immediately from 70 to 62 years. In addition, five-year experience became necessary to be a judge of the Curia due to the term of the Act CLXII of 2011 (2013) on the Legal Status and the Remuneration of Judges. This term was intentionally prohibited for Baka not to be a judge of Curia again by showing the reason of reorganising the judicial system in Hungary. In fact, Baka was a judge of ECtHR from 1991 to 2008 and then he was elected for six-year term by the Hungarian Parliament as a President of Supreme Court in 2009. Thus, he could be a judge until 2015. Unfortunately, the restriction of at least five-year experience of being a judge in Hungary was essential to be a judge. He criticised the actions of government related to the judicial reform as an experienced judge. The most important point was that he had no right to hear the case before the Constitutional Court and when he made the complaint to the Court, the Court rejected his complaint by the reason of reforming the judiciary. The alteration of the court system is one of the three exceptions to the principle of irremovability recognised by the Council of Europe. However, the reason given by Hungary under this exception was not acceptable due to the Baka case. Therefore, in 2016, the ECtHR found that Hungary violated freedom of speech (Article 6 (1) of ECHR) and fair trial right (Article 10 of ECHR) of the ECHR and European standard on the independence of judiciary and rule of law (Cannoot, 2016).

The principle of irremovability of judges came as a result of this kind of the removal of judges which had been made by the impeachment of the legislature and also by orders of the executive. Since former times, removal of judges from Supreme Courts was popular for the executive and the legislature if the decisions of the Courts ran contrary to their wishes.

\section{CONCLUSION}

The competencies of the Constitutional Court have been updated in Hungary and it is also a member of EU. So, the Court's power is also wider than before and the citizens of Hungary have the opportunities of enjoying not only the national fundamental rights but also the EU citizens' rights. The functions of the national Constitutional Court need to be stable and free from the influence of political affairs. If we consider the functions of the Constitutional Court in Hungary, one of the important functions of the Court has been abolished and the constitutional complaint was inserted instead of it due to the Constitution 2011. Even though actio popularis was famous for the protection of the fundamental rights before, this kind of constitutional complaint could not do so after the Constitution 2011 coming into force (Baka v Hungary, no. 20261/12). EU accepts a country that values democracy and human rights based on the rule of law as a member of the EU. After becoming a member of the EU, that country should obey the values of 
the EU prescribed in the EU treaties. Otherwise, the EU has the power to sanction and fine that country because of failures in following EU law harmony with the EU countries (Townley, 2019). The reasons why most of the European countries establish separate Constitutional Courts is that they are essential to keep democracy, to protect human rights and to implement the image of rule of law for both the governments and the governed. Therefore, the independence of the judiciary is also important to be guaranteed by the government and the duty to protect it is the responsibility of Constitutional Courts or Supreme Courts in some countries.

Finally, even though the politics have been changed, the principle of judicial independence and the irremovability of judges should not be violated in a democratic state and under the regional integration.

\section{REFERENCES}

1. Act CLXII of 2011 on the Legal Status and the Remuneration of Judges, (2013). Available at: https:// hunconcourt.hu/kozlemeny/the-constitutional-review-of-the-act-on-the-organisation-andadministration-of-the-courts-and-the-act-on-the-legal-status-and-remuneration-of-the-judges/.

2. Cannoot, P. (2016). Baka v. Hungary: Judicial Independence at risk in Hungary's new Constitutional reality. Available at: https://strasbourgobservers.com/2016/07/12/ baka-v-hungary-judicial-independence-at-risk-in-hungarys-new-constitutional-reality.

3. Consolidated Version of The Treaty on the Functioning of the European Union, (2008). Official Journal of the European Union. Available at: https:/ / eur-lex.europa.eu/.

4. Council of the European Union, (2018). Sanctions: how and when the EU adopts restrictive measures. Retrieved 16 April 2019. Available at: https://www.consilium.europa.eu/en/policies/ sanctions/.

5. Detre, L. (2019). Lecture on the Functioning of the Court and recent decisions, (Counselor, Constitutional Court), Constitutional Court, Budapest. Szechenyi Istvan University: Gyor, Hungary.

6. EU Directive 78/2000/EU, (2000). Available at: eur-lex.europa.eu/LexUriServ. do?uri=CELEX:32000L0078:EN:HTML.

7. European Commission For Democracy Through Law, (2012). The Transitional Provision to the Fundamental Law of Hungary. Available at: https://www.venice.coe.int/webforms/documents/default.aspx?pdffile=CDL-REF(2012)018-e.

8. European Commission v. Hungary C-286/12, (2016). Avaliable at: http://curia.europa.eu/juris/ document $/$ document.jsf?text $=\&$ docid $=129324 \&$ pageIndex $=0 \&$ doclang $=E N \&$ mode $=1$ st $\&$ dir $=$ \&occ $=$ first\&part $=1 \&$ cid $=7612094$.

9. Hungary's Constitution of 2011, (2019). Retrieved 10 February 2019. Available at: https://www. constituteproject.org/constitution/Hungary_2011.pdf.

10. Hungary: Act CLI of 2011 on the Constitutional Court (2011). Available at: https:/ / www.refworld. org/docid/4c345b5b2.html.

11. Somody, B., Vissy, B. (2011). Citizen's Role in Constitutional Adjudication in Hungary: from the Actio Popularis to the Constitutional Complaint. Available at: https://www.ajk.elte.hu/file/ annales_2012_05_SomodyVissy.pdf.

12. Szalbot, B. (2019). Essay on Constitutional Complaint in Hungary. Available at: https://www. academia.edu/21638505/Constitutional_complaints_in_Hungary.

13. The Constitutional Court of Hungary (1990). ABH Constitutional Court Decision. Available at: https:hunconcourt.hu/.

14. Townley, Ch., (2019). United in Diversity: Why we need less (not more) uniformity in (national and EU) competition policy and environment in Europe. Retrieved 15 June 2019. Available at: https:/ / eulawenforcement.com/?p=1004.

15. United Nations (1948). Universal Declaration of Human Right. Retrieved 23 April 2019. Available at: https://www.ohchr.org/en/udhr/documents/udhr_translations/eng.pdf.

16. Vincze, A. (2014). Judicial Independence and Its Guarantees Beyond the Nation State-Some Recent Hungarian Experience. Journal of the Indian Law Institute, 56 (2), 202-215. 